\title{
Palavras capitais na história dos reis, dos infantes e dos navegadores
}

\author{
Susani Silveira Lemos França ${ }^{1 *}$ \\ ${ }^{1}$ Universidade Estadual Paulista, Franca, São Paulo, Brasil
}

\section{RESUMO}

No Portugal do século XV, as crônicas e os relatos de viagem dedicados ao passado dos reinos e ao avanço por terras africanas mostram-se estruturados a partir de certas ideias gerais, como ordenar, não deixar esquecer, ensinar os que hão de vir e evitar toda e qualquer falsidade. Esses dois tipos de narrativas com função ordenadora do passado lançam mão de um jogo vocabular relativamente homogêneo em torno de algumas palavras, a saber: a graça, a virtude e a obediência. Tais palavras, como será examinado neste estudo, por sua recorrência, revelam-se elos ou eixos moralizadores para justificar e ornar as açóes dos protagonistas das histórias de então: os reis, os infantes e os navegadores.

Palavras-chave: expansão quatrocentista; Portugal; crônicas; relatos de viagem; moralidade.

\section{Major Words in the History of Kings, Infantes and Navigators}

\section{ABSTRACT}

In Portugal in the $15^{\text {th }}$ century, chronicles and travel accounts dedicated both to the past of the kingdoms and to the ever-deeper incursions into African lands are structured around certain general ideas, like ordering, not letting people forget, teaching those who are to come, and avoiding all and any falsehood. These two types of narratives with the role of organizing the past make use of a relatively homogeneous vocabulary that revolves around a few specific terms: grace, virtue and obedience. These words, as it will be examined in the present study, by their recurrence, reveal themselves as moralizing links or axes to justify and adorn the actions of the protagonists of the stories of that time: kings, infantes and navigators.

Keywords: $15^{\text {th }}$-century expansion; Portugal; chronicles; travel accounts; morality.

DOI: http://dx.doi.org/10.1590/2237-101X01903904

Artigo recebido em 3 de outubro de 2017 e aprovado para a publicação em 17 de fevereiro de 2018.

*Professora da Universidade Estadual Paulista (Unesp). E-mail: susanilemos@uol.com.br.

Este trabalho é resultado de pesquisa desenvolvida no âmbito do Projeto Temático "Escritos sobre os Novos Mundos (...)", financiado pela Fapesp (Processo n. 2013/14786-6). 


\section{Palabras capitales en la historia de los reyes, infantes y navegadores}

\section{RESUMEN}

En Portugal del siglo XV, las crónicas y los relatos de viaje dedicados al pasado de los reinos $\mathrm{y}$ al avance por tierras africanas se muestran estructurados a partir de ciertas ideas generales como ordenar, no dejar olvidar, enseñar a los que han de venir, y evitar a toda y cualquier falsedad. Esos dos tipos de narrativas con función ordenadora del pasado lanzan mano de un juego léxico relativamente homogéneo que gira en torno a algunas palabras, a saber: la gracia, la virtud y la obediencia. Estas palabras, como será examinado en este estudio, por su recurrencia, se revelan como vínculos y ejes para justificar y ornar las acciones de los protagonistas de las historias de la época: los reyes, los infantes y los navegadores.

Palabras clave: expansión del siglo XV; Portugal; crónicas; relatos de viaje; moralidad.

Tida outrora como mero meio de exprimir experiências passadas e presentes, a língua, desde o último século, vem sendo reconhecida pelo seu potencial muito mais alargado de conferir inteligibilidade a experiências que, por si, não teriam qualquer significado. ${ }^{1} \mathrm{~A}$ diversidade do mundo real, em qualquer época, só pode ser dada a conhecer por meio de um sistema relativamente móvel de convençôes de ordem sintática e fonética. ${ }^{2}$ A partir do século XIII, as línguas vernáculas avançaram, em Castela e Portugal mais ligeiramente, ${ }^{3}$ pelo mundo dos escritos em concorrência com o latim, até então prestigiado como língua da Bíblia e transmissora, através dos tempos, da palavra de Deus. ${ }^{4}$ Nos primeiros séculos em que essas línguas conquistaram espaço como expressão das leis e das coisas do espírito, ${ }^{5}$ entretanto, ainda não existiam normas de registro que conferissem unidade aos textos. $\mathrm{O}$ que havia e garantia o reconhecimento dos escritos eram apenas regras genológicas e retóricas, que serviam tanto como recurso de ordenação das ideias quanto de seleçáo de citaçóes

\footnotetext{
${ }^{1}$ GADAMER, Hans-Georg. Verdade e método. Traços fundamentais de uma hermenêutica filosófica. Tradução de Flávio Paulo Meurer; revisão de Ênio Paulo Giachini. Petrópolis: Vozes, 1999, 2v.

${ }^{2}$ BOISSELIER, Stéphane; DARBORD, Bernard; MENJOT, Denis. Langues Médiévales Ibériques. Domaines espagnol et portugais. MARTIN, George; MOLÉNAT; Jean-Pierre; TEYSSIER, Paul (Col.). Turnhout: Brepols Publishers, 2012. (Collection L’Atelier du Médiéviste 12), p. 8.

${ }^{3}$ Idem.

${ }^{4}$ FOURNIÉ, Michelle; LE BLÉVEC, Daniel; HENRIET, Patrick et al. La parole sacré. Formes, fonctions, sens $\left(\mathrm{XI}^{\mathrm{e}}-\mathrm{XV}^{\mathrm{e}}\right.$ siècle). Cahiers de Fanjeaux — Publication annuelle d'histoire religieuse du Midi de la France au Moyen Âge 47. Toulouse: Privat, 2013, p. 15.

${ }^{5}$ Em Portugal, no século XV, passa a ser corrente nos escritos filosóficos. CARVALHO, Mário Santiago de. Uma modernidade perdida. Da melancolia à alegria racional na antropologia do homem superior, segundo D. Duarte. Revista Filosófica de Coimbra, n. 43, p. 187-206, 2013, p. 188.
} 
de textos anteriores, de expressôes imprescindíveis e de autoridades incontornáveis. ${ }^{6}$ Entre essas leis dos gêneros, que serviam também como forma de legitimação, os vocábulos de teor moralizador cumpriam um papel sobremodo significativo, pois conferiam certa estabilidade e compensavam a ausência de padróes de escrita que só no século seguinte começam a ser criados. ${ }^{7}$ Nos registros mais facilmente identificáveis como do passado, como as crônicas, as vidas de santos e os relatos de viagem — que oscilam entre informar e instruir —, é especialmente notável o peso das palavras de fundo religioso; palavras que se configuram como uma maneira mais ou menos direta de expressão ou instrumento da teologia moral, que orientava as condutas e as aspiraçóes. ${ }^{8}$

No contexto em que a soberania de Portugal tinha já se firmado, depois da crise sucessória de 1383-1385, e os filhos de d. João I, desde a segunda década do século XV, vinham-se empenhando em alçar voos mais altos - como as conquistas de praças no norte da África e os avanços para além do Cabo Bojador - as formas de predicação nas fontes escritas em linguagem ${ }^{9}$ tornaram-se mais difusas e diversas. Se atentarmos para alguns desses relatos ou crônicas do período da expansão portuguesa pela África, as convençôes moralizantes mostram-se organizadas em torno de certos vocábulos que náo se restringem a determinado gênero, ou seja, denunciam convençôes sociais que vão para além das retóricas. Afirmação, entretanto, que não deve fazer esquecer que cada qual dos gêneros escritos correntes no Quatrocentos, como crônicas, epístolas, roteiros, vidas, entre outros, constitui um universo regrado e relativamente uniforme, com particularidades que permitem falar em um conjunto à parte. Tampouco pode fazer esquecer que cada exemplar de um qualquer desses gêneros pode ser pensado como autônomo em relação às demais peças, dado ser destinado a um fim específico, como narrar uma vida ou um feito ou simplesmente demarcar percursos. Mas, a despeito das especificidades do conjunto ou de cada espécime, eles lançam certo enfoque sobre a realidade que partilham ou dão forma a ela segundo valores correntes que transcendem os objetivos específicos. ${ }^{10}$ São justamente essas reflexôes morais difusas, não sistematizadas e diretas como nos tratados morais, ${ }^{11}$ que nos interessam particularmente neste estudo, isto

\footnotetext{
${ }^{6}$ BOISSELIER, Stéphane; DARBORD, Bernard; MENJOT, Denis. Langues Médiévales Ibériques, op. cit., p. 9. ${ }^{7}$ As gramáticas quinhentistas são exemplo dessa preocupação em estabelecer certos padrôes e regras. Cf. OLIVEIRA, Fernão de. A Gramática da Linguagem Portuguesa. Introdução, leitura atualizada e notas por Maria Leonor Carvalhão Buescu. Lisboa: Imprensa Nacional — Casa da Moeda, 1975.

${ }^{8}$ BAÑOS VALLEJO, Fernando. Las vidas de santos en la literatura medieval española. Madri: Laberinto, 2003 , p. 80.

9 "Linguagem, subs. (do lat. Medieval linguagiu-m. pelo provençal lenguatge). A comunicação humana; idioma; língua romance ou portuguesa." MACHADO, José Barbosa (Ed.). Dicionário dos primeiros livros impressos em língua portuguesa. Braga: Ediçóes Vercial, 2015, v. 3, p. 129.

${ }^{10}$ BAÑOS VALLEJO, Fernando. Las vidas de santos en la literatura medieval española, op. cit., p. 152.

${ }^{11}$ Como os de Alain de Lille, Hugo de São Victor, em outras partes. Cf. CASAGRANDE, Carla; VECCHIO, Silvana. Les péchés de la langue. Discipline et éthique de la parole dans la culture médiévale. Paris: Cerf, 1991, p. 19 et. seq. E de d. Duarte, do infante d. Pedro, em Portugal. Cf. CALAFATE, Pedro. História do pensamento filosófico português. Lisboa: Caminho, 1999, p. 379-444.
} 
é, a maneira como, fazendo jus ao caráter missionário da fé que os conduz, ${ }^{12}$ exprimem algo do seu mundo com o fim de instruir e preservar o que se aceitava como bom. Em outras palavras, é a moralização pelos exemplos práticos e não tanto pela definição, classificação e explicação das virtudes e dos vícios, como nos tratados morais, o que importa examinar aqui.

A história da guerra pela soberania, mesmo depois da conquista de Ceuta, tinha ainda conduzido o fazer do primeiro cronista régio português, Fernão Lopes; todavia, seu sucessor, Gomes Eanes de Zurara, centra sua história em torno dos feitos de ampliação do reino, pois escreve a partir de 1450 , quando os avanços expansionistas já náo eram entre vizinhos ${ }^{13} \mathrm{e}$ denunciavam, tal como em Castela, os sonhos de conquistar mundos desconhecidos. ${ }^{14}$ Das palavras nos escritos em língua vulgar, nesse período, que coincidem na definição da exemplaridade quando se trata de falar de reis memoráveis ou cavaleiros destemidos que deixaram seu lar em nome do reino e da fé, algumas, vindas do latim, ganham estabilidade em português nesse período: a graça, ${ }^{15}$ a virtude ${ }^{16} \mathrm{e}$ a obediência. ${ }^{17}$ Nas narrativas sobre as primeiras expediçóes portuguesas para a costa ocidental da África, ainda em meados do século XV e sob o comando do infante d. Henrique, a conjugaçáo entre o objetivo de reconhecimento das terras, de contato com povos não cristianizados e de eventual evangelização e comércio ${ }^{18}$ favorece a recorrência dessas palavras que traduzem a ideia de uma unidade do ser cristáo. Seu uso não era certamente uma novidade, mas os elos históricos entáo estabelecidos trazem nuances que denunciam certo avanço dos poderes e dos valores regionais em detrimento do

\footnotetext{
${ }^{12}$ VAUCHEZ, André. Présentation. In: Faire Croire. Modalités de la diffusion et de la réception des messages religieux du XII e au XVe siècle. Org. por l'École Française de Rome, em colaboração com l'Institut d'Histoire Médiévale de l'Université de Padoue (Roma, 22-23 jun. 1979). Paris: École Française de Rome — Palais Farnése, 1981, p. 9.

${ }^{13}$ Das diversas histórias dos primeiros passos da expansão portuguesa, vale destacar: MARQUES, Oliveira A. H. Nova história da expansão portuguesa. Vol. II: A expansão quatrocentista. Lisboa: Estampa, 1998.

${ }^{14}$ DE ANDRADE, António Alberto Banha. Mundos novos do mundo: panorama da difusão, pela Europa, de notícias dos descobrimentos geográficos portugueses. Lisboa: Junta de Investigaçóes do Ultramar, 1972, p. 33; RUCQUOI, Adeline. Mancilla y limpieza: la obsesión por el pecado en Castilla a fines del siglo XV. In: Rex, sapientia, nobilitas. Estúdios sobre la Península Ibérica Medieval. Granada: Universidade de Granada, 2006 , p. 249.

15 "Graça, subs (do lat. gratia-m). Favor que se dispensa ou se recebe; dom sobrenatural; mercê; agradecimento." MACHADO, José Barbosa (Ed.). Dicionário dos primeiros livros impressos em lingua portuguesa, op. cit., v. 2, p. 549.

16 "Virtude, subs (do lat. virtute-m). O conjunto das qualidades que dão valor a uma pessoa: qualidade moral; força moral; retidáo." Ibidem, v. 4, p. 456.

17 "Do lat. oboedientia-m. Ato ou efeito de obedecer; submissão; sujeição; um dos três votos religiosos." Ibidem, v. 3, p. 316.

${ }^{18}$ Sobre a guerra além-fronteiras ou além-mar, Maria Helena da Cruz Coelho propóe uma conciliação de motivaçóes que traduz bem o momento: "equilíbrios políticos, as necessidades económicas vitais, a aventura e o espírito evangelizador e de cruzada (...). COELHO, Maria Helena da Cruz. O Estado e as sociedades urbanas. In: COELHO, Maria Helena da Cruz; CARVALHO HOMEM, Armando Luís de (Org.). A génese do Estado Moderno no Portugal tardo-medievo (séculos XIII-XV). Ciclo temático de conferências organizado pela Universidade Autónoma de Lisboa no ano letivo de 1996/97. Lisboa: Universidade Autónoma de Lisboa, 1999, p. 269-292, p. 273.
} 
universalismo cristão. ${ }^{19}$ Reis, infantes, capitães e outros navegadores foram, nessa altura, as figuras cujo exemplo justificava ser preservado para a posteridade na forma escrita, por sua atuação na ampliação, a partir de Portugal, das fronteiras da Cristandade no século XV. Nas narrativas sobre seus feitos, esses pilares, que cobrem desde o fundamento da existência à sua condução e ao seu aperfeiçoamento, são reincidentes e cumprem função legitimadora e engrandecedora.

A "graça divinal" e o "natural entender" são indicados como os principais motores para "seguirem as obras boas ou más". ${ }^{20} \mathrm{O}$ referido cronista conhecido como o primeiro da expansão, Gomes Eanes de Zurara, para refletir sobre a propensão da nobreza para "suportar coisas grandes e fortes" em busca de honra e glórias, recorda, na crônica sobre o governador português em Ceuta, d. Duarte de Menezes, um ensinamento essencial do filósofo dominicano alemão Alberto Magno: a máxima de que nas mãos de Deus estão "todas as coisas", dado que ele seria o primeiro motor na ordem do conhecimento, bem como na ordem do ser, ${ }^{21}$ estando tudo no intelecto da causa primeira. ${ }^{22}$ Todo "dom comprido e perfeito", acrescenta o cronista a partir dele, só podia descender do "pai dos lumes" ou do "sumo dador", a quem prouve conceder aos homens "entendimento e memória" para que pudessem se "desviar das coisas contrárias e chegar às proveitosas". ${ }^{23}$ Toda ação virtuosa ou conhecimento verdadeiro, nesse sentido, suporia graça divina. ${ }^{24}$ Do mesmo modo, a ação de preservar a verdadeira fé e expandi-la para territórios pouco conhecidos, mais ainda, era e devia ser movida de um plano mais elevado.

A fórmula ou convenção pela ou com a "graça de Deus" 25 para não falar do "graças a Deus", que aparece como louvor ou reconhecimento pelo alcançado — liga-se às personagens das crônicas e relatos, como ao referido d. Duarte de Menezes. Tal fórmula configura-

${ }^{19}$ Desde o século XIV, como explica Bernard Guenée, os Estados “mais fortes sujeitavam-se menos a autoridade de uma Igreja universal”. Sua referência é sobretudo ao jogo político, mas cujas consequências socioculturais não podem ser negligenciadas. Cf. GUENÉE, Bernard. Entre l'Église et l'État. Paris: Gallimard, 1987, p. 18. ${ }^{20}$ ZURARA, Gomes Eanes de. Crónica de D. Duarte de Meneses. Edição diplomática de Larry King. Lisboa: Universidade Nova de Lisboa, 1978, p. 135.

${ }^{21}$ GILSON, Étienne. O espírito da filosofia medieval. Tradução de Eduardo Brandão. São Paulo: Martins Fontes, 2006, p. 343.

${ }^{22}$ Segundo Tomás de Aquino: "A graça é uma certa semelhança com Deus de que o homem participa" (III, 2, 10 ad 1); "O primeiro efeito da graça é conferir um ser de alguma forma divino" (III, 2 d. 26, 155). Cf. LAUAND, Jean. Razão, natureza e graça: Tomás de Aquino em sentenças. Sáo Paulo: Edix, 1995. Disponível em: <http://www.hottopos.com/mp3/sentom.htm\#agra>. Acesso em: 30 abr. 2017.

${ }^{23}$ ZURARA, Gomes Eanes de. Crónica de D. Duarte de Meneses, op. cit., p. 135.

${ }^{24}$ Segundo Etiene Gilson a propósito de Alberto Magno: "Na medida do possível, cada alma é um quod est distinto, que Deus atualiza conferindo-lhe esse quo est que é a existência. Se ele concede a existência a essas naturezas intelectuais, é para que elas possam ser iluminadas pela luz dele." (...) "o homem necessita, para conhecer, de uma luz mais abundante que a sua própria luz..." GILSON, Etienne. A filosofia na Idade Média. Tradução de Eduardo Brandão. São Paulo: Martins Fontes, 2001, p. 637, p. 639-640.

${ }^{25}$ Fórmula que Nieto Soria explorou nos escritos como índice da sacralização régia. NIETO SORIA, José Manuel. Imágenes religiosas del rey y del poder real en la Castilla del siglo XIII. En la España medieval, v. 9, p. 709-729, 1986. 
-se, por um lado, como um recurso para rememorar sua condição essencial de pecadores, porém, sujeitos ao socorro divino para se reabilitarem; por outro, como uma maneira de reafirmar o caráter divino ou sagrado das ações ou empreendimentos por eles levados a cabo. D. Duarte, um dos pensadores portugueses que mais colaborou para o desenvolvimento dos escritos em romance — de próprio punho ou por demanda ${ }^{26}$ —, incidiu diretamente sobre a reflexão ética e moral, ${ }^{27}$ ou melhor, procurou associar saber, agir e prática da virtude, ${ }^{28}$ contribuindo para a rememoração do papel da graça, própria das criaturas racionais, ${ }^{29}$ como recurso para reverter a propensão ao pecado, ${ }^{30}$ ao lado da boa vontade e dos bons ensinamentos. Nos seus escritos, ele atualiza a tópica cristã da determinação da ajuda da graça na sua reflexão sobre as partes do entendimento, afirmando que, para a preservação destas, seriam necessários a temperança nos atos, a evitação dos descontroles das paixóes e medos e o apreço por segui-las. Mas, primeiramente e principalmente, era preciso não perder de vista que era "por sua especial graça” — ou seja, pelo conhecimento da graça de Deus — que "todo nosso bem" se alcançava. ${ }^{31}$ Concedida gratuitamente por Deus para ajudar o homem a vencer sua deficiência original ${ }^{32}$ e retomar o caminho de volta a Ele, a graça é, portanto, a intermediária indispensável, juntamente com a vontade, para fortalecer o homem em busca de Deus. ${ }^{33}$ Assim, configura-se, paradoxalmente, como reconhecimento de Deus pelas boas açôes praticadas no passado e guia para as boas açôes futuras. ${ }^{34}$ Nas palavras do rei português, era ela que socorria nos tempos de necessidade, juntamente com a sabedoria e os bons exemplos; ${ }^{35}$ estando estes exemplos, como ensinavam grandes pensadores cristáos, condicionados àquela, ${ }^{36}$ por ser ela garantidora do conhecimento verdadeiro. ${ }^{37}$

\footnotetext{
${ }^{26}$ Vale recordar que se deve a ele a criação de um ofício destinado à construção da história.

${ }^{27}$ GAMA, José. A filosofia da cultura portuguesa no Leal Conselheiro de D. Duarte. Lisboa: Fundação Calouste Gulbenkian, 1995, p. 17-18.

${ }^{28}$ CALAFATE, Pedro. História do pensamento filosófico português, op. cit., p. 384.

29 SENELLART, Michel. O Policraticus de João de Salisbury (1115/20-1180): uma ética real da salvação pública. In: CAILLÉ, Alain; LAZZERI, Christian; SENELLART, Michel. História argumentada da filosofia moral e política: a felicidade e o útil. São Leopoldo: Unisinos, 2004, p. 155-160, p. 158.

${ }^{30}$ Por fazer renascer a vontade de fazer o bem. DELHAYE, Ph.; LECLERCQ, J.; HÄRING, B.; VOGEL, C.; NODET, Ch. H. La pastorale du péché. Tournai: Desclée \& Cie, 1961, p. 6.

${ }^{31}$ DOM DUARTE. Leal conselheiro. In: Obras dos principes de Avis. Edição de Manuel Lopes de Almeida. Porto: Lello \& Irmão - Editores, 1981, p. 241.

${ }^{32}$ DELHAYE, Ph.; LECLERCQ, J.; HÄRING, B.; VOGEL, C.; NODET, Ch. H. La pastorale du péché, op. cit., p. 11.

${ }^{33}$ Segundo a síntese de São Boaventura. GILSON, Etienne. A filosofia na Idade Média, op. cit., p. 546.

34 SANCHEZ, Clemente. Sacramental. Edição semidiplomática, introdução, lematização e notas de José Barbosa Machado. Braga: Ediçóes Vercial, 2010, p. 56-57. Uma ascese moral guiada pela graça é reconhecida em pensadores fundamentais da Baixa Idade Média, como João de Salisbury. SENELLART, Michel. O Policraticus de João de Salisbury (1115/20-1180): uma ética real da salvação pública, op. cit., p. 160.

${ }^{35}$ DOM DUARTE. Livro da ensinança de bem cavalgar toda. Edição crítica por Joseph M. Piel. Lisboa: Imprensa Nacional — Casa da Moeda, 1986, cap. XV, p. 120-121.

${ }^{36}$ DOM DUARTE. Leal conselheiro, op. cit., p. 239.

${ }^{37}$ GILSON, Etienne. A filosofia na Idade Média, op. cit., p. 639-640.
} 
Igualmente emoldurados pela graça ou com seus feitos garantidos ou legitimados por esta sáo outros personagens dos registros quatrocentistas responsáveis por ampliar o reino e expandir a fé católica, como se propalava. $\mathrm{Na}$ crônica considerada pioneira entre os relatos da expansão portuguesa, a Crônica da tomada de Ceuta, além de o cronista conclamar para si, como narrador dos feitos notáveis, "os átomos daquela graça" concedida aos santos apóstolos, ${ }^{38}$ agradecendo a seguir pela graça recebida, ${ }^{39}$ inúmeras são as inclusôes do rótulo pela graça de Deus. O infante d. Henrique, quando argumenta com o pai as razóes que justificavam a empresa portuguesa sobre Ceuta, recorda-lhe, entre outros argumentos, que o seu próprio título de rei não era senão pela "graça" de Deus ${ }^{40}$ e recebe autorização do rei para prosseguir o feito sob igual argumento de que o faria com sua "graça e ajuda" ${ }^{\text {”11 }}$ - sem as quais nada seria possível, como o cronista adianta logo no início do relato. ${ }^{42}$ Do mesmo modo o infante e seus irmãos recordam à rainha d. Felipa, para demandar sua aprovação para a empresa em Ceuta, que a "alteza do seu sangue" tinha sido alcançada pela "graça de Deus". ${ }^{3}$

Por sua recorrência e por oscilar entre o louvor e o agradecimento a Deus pelas glórias do passado e a garantia e promessa de sucessos, a graça assume claramente o referido sentido de fundamento das açôes boas ou louváveis. Na conversação travada entre o rei d. João e a rainha d. Filipa a propósito dos projetos conquistadores dos filhos no norte da África, o rei dá "graças a Deus" pelo ensejo da aprovação da empreita pela rainha e, logo depois, estima que a obra, "com a graça de Deus (...), venha a proveitoso fim". ${ }^{44}$ Ornando o passado, o presente e o futuro, a mão ou a luz de Deus, nesses escritos históricos, exerce domínio absoluto. Por um lado, esse domínio é exercido em prol dos seus protegidos: concedendo aos reis seus cargos e amparando-os no seu exercício; ${ }^{45}$ dotando reis e nobres de qualidades e virtudes; ${ }^{46}$ predestinando cavaleiros para grandes empresas, como a conquista de praças marroquinas; ${ }^{47}$ capacitando cronistas para registrar grandes feitos ${ }^{48}$ concedendo coragem aos cavaleiros nas

${ }^{38}$ ZURARA, Gomes Eanes de. Crónica da Tomada de Ceuta. Edição de Francisco Maria Esteves Pereira. Coimbra: Imprensa da Universidade, 1915, p. 7-8. Também na p. 11 diz escrever com a graça de Deus.

${ }^{39}$ Ibidem, p. 274.

${ }^{40}$ Ibidem, p. 46.

${ }^{41}$ Ibidem, p. 48.

${ }^{42}$ Ibidem, p. 8.

${ }^{43}$ Ibidem, p. 61.

${ }^{44}$ Ibidem, p. 63 e p. 131.

${ }^{45}$ PINA, Rui de. Chronica do senhor rey D. Duarte. In: Crónicas de Rui de Pina. D. Sancho I, D. Afonso II, D. Sancho II, D. Afonso III, D. Dinis, D. Afonso IV, D. Duarte, D. Afonso V, D. João II. Introdução e revisão de M. Lopes de Almeida. Porto: Lello \& Irmão - Editores, 1977, cap. II, p. 493.

${ }^{46}$ Ibidem, p. 495; ZURARA, Gomes Eanes de. Crónica de D. Duarte de Meneses, op. cit., p. 54.

${ }^{47}$ ZURARA, Gomes Eanes de. Crónica de Guiné. Introdução, novas anotaçôes e glossário de José de Bragança. Lisboa: Livraria Civilização, 1973, p. 47; PEREIRA, Duarte Pacheco. Esmeraldo de Situ Orbis. Introdução e anotaçóes históricas de Damião Peres. Lisboa: Academia Portuguesa de História, 1988, p. 78-79.

48 ÁLVAREZ, João. Chronica do Infante Santo D. Fernando. Edição crítica por Mendes dos Remédios. Coimbra: F. França Amado, 1911, p. 3. 
batalhas $;^{49}$ restituindo-lhes a saúde por feridas de combate ${ }^{50}$ ou, mormente, preservando-lhes a vida. ${ }^{51}$ Por outro lado, essa mesma mão de Deus age em prejuízo dos oponentes: livrando os cristãos dos mouros de Ceuta; ${ }^{52}$ causando "mortal dano" aos inimigos; ${ }^{53}$ contendo os numerosos adversários; ${ }^{54}$ fazendo com que muitos parecessem poucos aos olhos dos cristãos; ${ }^{55}$ levando a recuar carregados de mortos aqueles que trabalharam por "danar" os comarcôes. ${ }^{56}$ Esse pilar da moral cristã ganha forma nesses escritos como legitimador dos projetos conquistadores dos reis sobre povos não cristáos, bem como legitimador das açôes de cavaleiros que dependiam da força, da coragem e do derramamento de sangue para que passassem para a história como motivados por Deus e atuantes ao seu serviço.

Como a graça, a virtude é outra palavra que legitima os escritos e as açóes neles descritas. Se a primeira se anunciava como fundamento destas, ou seja, se as açôes virtuosas eram entendidas como movidas ou possíveis pela graça e seu prolongamento no tempo igualmente garantido por esta, a virtude, por sua vez, conquista poder substantivo em diversas situaçôes. É ela que aparece como necessária para se alcançar a graça e enfrentar o pecado. Como condutora da vida com retidão e bem-aventurada,${ }^{57}$ a virtude, ${ }^{58}$ essencialmente entendida como meio para reverter a condiçáo original de pecador e como disposiçáo para realizar com excelência aquilo para o que se está destinado ${ }^{59}$ surge nos relatos seja como consequência da intervenção divina, seja como condição para alcançar a graça — no duplo sentido de auxílio ou favor dados por Deus e de recompensa divina. Não são poucas as vezes que vemos nas narrativas a afirmação de que "nenhum bem fazer não convém aos homens se não por azo do Senhor Deus", ${ }^{60}$ por consequência, nenhuma disposição pode ser chamada de virtude se estiver em desacordo com a vontade divina. ${ }^{61}$ Como causa primeira de toda e qualquer

${ }^{49}$ Chronica do Condestabre de Portugal. Com revisão, prefácio e notas por Mendes dos Remédios. Coimbra: França Amado, 1911, p. 123-124.

${ }^{50}$ ZURARA, Gomes Eanes de. Crónica do Conde Dom Pedro de Meneses. Nota de apresentação de José Adriano de Freitas Carvalho. Fac-símile da edição do Abade Correia da Serra, de 1792, Academia das Ciências de Lisboa. Porto: Programa Nacional de Ediçóes Comemorativas dos Descobrimentos Portugueses, 1988, p. 212.

${ }^{51}$ Ibidem, p. 222, 248.

${ }^{52}$ ÁLVAREZ, João. Chronica do Infante Santo D. Fernando, op. cit., p. 34.

${ }^{53}$ Ibidem, p. 28.

${ }^{54}$ ZURARA, Gomes Eanes de. Crónica de D. Duarte de Meneses, op. cit., p. 446.

${ }^{55}$ ZURARA, Gomes Eanes de. Crónica do Conde Dom Pedro de Meneses, op. cit., p. 484.

${ }^{56}$ Ibidem, p. 486.

${ }^{57}$ VAZ, Henrique C. de Lima. Escritos de filosofia IV. Introdução à ética filosófica. São Paulo: Ediçóes Loyola, 2009, p. 233; GILSON, Étienne. O espírito da filosofia medieval, op. cit., p. 397.

${ }^{58}$ Aparece também no sentido de fortaleza, valentia, como na Crónica de Guiné. ZURARA, Gomes Eanes de. Crónica de Guiné, op. cit., p. 4 e 71.

${ }^{59}$ Ideia que os cristãos retomarão dos antigos, porém, dirigindo CAILLÉ, Alain; LAZZERI, Christian; SENELLART, Michel. História argumentada da filosofia moral e política: a felicidade e o útil, op. cit., p. 20.

${ }^{60}$ ZURARA, Gomes Eanes de. Crónica da Tomada de Ceuta, op. cit., p. 4.

${ }^{61}$ CAILLÉ, Alain; LAZZERI, Christian; SENELLART, Michel. História argumentada da filosofia moral e politica: a felicidade e o útil, op. cit., p. 22. 
ação, Deus se configura também como finalidade, ${ }^{62}$ de modo que as virtudes dos homens aparecem como sua concessáo, melhor, como resultado de sua vontade e, em contrapartida, como via para a aproximação de sua plenitude. ${ }^{63}$

$\mathrm{Na}$ Crónica de Guiné, em que o cronista Zurara não se constrange em registrar os mais altos elogios ao infante d. Henrique - definindo-o como "príncipe pouco menos que divinal" ${ }^{64}$ —, as virtudes são apresentadas como atributos principais daqueles que são indicados como predestinados. ${ }^{65}$ Em outras palavras, são elas tidas como "mercês" de Deus, ${ }^{66}$ chegando até mesmo a receber do cronista o designativo de "sagradas", ${ }^{67}$ que faz justamente recordar a relaçáo com o transcendente. ${ }^{68}$ Quando se refere à fé do infante, expressa na forma de amor e temor ao Senhor, ${ }^{69}$ o cronista a enquadra como um dos dons gratuitos de Deus, ${ }^{70}$ ao lado da esperança e da caridade, e configurando-se como condiçấo para a realização plena das demais virtudes. Ideia ratificada a seu propósito pelo cosmógrafo Duarte Pacheco Pereira no início do século XVI, ao registrar que os varóes dotados de virtudes "nunca são desamparados da graça do Espírito Santo..."; ${ }^{71}$ ou quando anuncia que o príncipe "prudente e virtuoso" parecia "iluminado da graça do espírito santo e movido por divinal mistério..."72

Tal relação com o transcendente é, do mesmo modo, lembrada na crônica de elogio ao infante d. Fernando, seu irmáo, que morreu no norte da África nas mãos dos mouros e cuja história, contada por seu confessor, frei João Álvarez, ganhou pinceladas de martírio. Registra esse frade que "Deus pôs nele e conservou muitas virtudes", ${ }^{73}$ tanto que parecia sempre agir "com ajuda divinal" ${ }^{74}$ Virtuosos pela graça de Deus são qualificados, a propósito, todos os membros da sua família, a quem os cronistas pintam como escolhidos da providência para levar a cabo grandes feitos. Mas mais reiteradas são as virtudes do infante d. Henrique,

${ }^{62}$ DOM PEDRO. Livro da virtuosa benfeitoria. In: Obras dos príncipes de Avis. Edição de Manuel Lopes de Almeida. Porto: Lello \& Irmão - Editores, 1981, p. 533.

${ }^{63}$ CAILLÉ, Alain; LAZZERI, Christian; SENELLART, Michel. História argumentada da filosofia moral e política: a felicidade e o útil, op. cit., p. 23.

${ }^{64}$ ZURARA, Gomes Eanes de. Crónica de Guiné, op. cit., p. 13.

${ }^{65}$ Ibidem, p. 47.

${ }^{66}$ Ibidem, p. 3.

${ }^{67}$ Ibidem, p. 13.

${ }^{68}$ DUPRONT, Alphonse. Du sacré: croisades et pèlerinages — images et langages. Paris: Gallimard, 1987, p. $87-88$.

${ }^{69}$ Os espelhos de príncipes ensinavam, por exemplo, que o temor e amor a Deus eram os princípios básicos que deviam guiar. Cf. RINCÓN, David Nogales. Los espejos de príncipes en Castilla (siglos XIII-XV): un modelo literario de la realeza bajomedieval. Medievalismo: Boletín de la Sociedad Española de Estudios Medievales, n. 16, p. 9-40, 2006, p. 21; ARMAS, Gregório. La moral de San Agustin. Madri: Asilo de Huérfanos del Sagrado Corazón de Jesus, 1955, p. 286-290.

${ }^{70}$ Sobre a fé como dom de Deus e confiança na autoridade divina em Agostinho: MARROU, Henri-Irenée. Saint Augustin et l'augustinisme. Paris: Seuil, 2003, p. 64.

${ }^{71}$ PEREIRA, Duarte Pacheco. Esmeraldo de Situ Orbis, op. cit., p. 78-79.

${ }^{72}$ Ibidem, p. 10.

${ }_{73}$ ÁLVAREZ, João. Chronica do Infante Santo D. Fernando, op. cit., p. 8.

${ }^{74}$ Ibidem, p. 82. 
inclusive em uma carta a d. Afonso V, na qual Zurara escreve que, "se alguns príncipes católicos neste mundo cobraram perfeição das virtudes heroicas, ${ }^{75}$ ele devia ser contado por um dos principais". ${ }^{76} \mathrm{E}$ a própria rainha, $\mathrm{d}$. Filipa, não é poupada de referências às suas virtudes e à sua fiança de que tudo provinha de Deus. Diante do risco de morrer durante a gravidez do seu filho Fernando, ela recusa o aborto, argumentando ao marido que não admitiria ser homicida de ninguém, menos ainda de alguém de sua "própria carne". ${ }^{77}$ Assim como a esposa, d. João I recebeu o reconhecimento por muitos de que "todas as humanais virtudes floresceram" nele. ${ }^{78} \mathrm{E}$ até mesmo o bastardo de d. João I, d. Afonso, $8^{\circ}$ conde de Barcelos, "fizera-o Deus tão virtuoso e de tamanha grandeza de coração, que em todas as coisas de honra escondia a baixeza do sangue da mãe", sendo dotado de grande siso. ${ }^{79}$

A intervenção divina, porém, não descartava o papel dos homens no aperfeiçoamento das virtudes. D. João I, na conhecida altercação ${ }^{80}$ com seu filho d. Henrique sobre a viabilidade da conquista de Ceuta, argumenta que "nenhuma virtude não pode ser em perfeição sem algum exercício" ${ }^{81}$ Falava em especial da virtude da fortaleza, então comumente confundida com a força, ${ }^{82}$ mas que se distinguia desta por depender mais do coração do que do corpo. Nascida do coração, a fortaleza, conjugada com a prudência — arte de deliberar de forma racional e reta ${ }^{83}$ —, permitia agir "sem nenhuma torvação" ${ }^{84} \mathrm{e}$, em contrapartida, permitia ao seu portador náo se esquivar de "obrar grandes coisas" ${ }^{85} \mathrm{O}$ empenho dos homens em exercitar essa, como outras virtudes, é comumente destacado nos relatos. Para além de se mostrarem convencidos do papel da graça como provedora do supremo bem — papel este recordado inúmeras vezes por aqueles que escrevem —, atribui-se aos protagonistas da primeira expansão portuguesa atenção para o valor das virtudes e especial cuidado no seu cultivo.

\footnotetext{
75 “(...) para ser heroica una virtud cristiana debe capacitar a su dueño para realizar acciones virtuosas con extraordinaria prontitud, facilidad y placer, por motivos sobrenaturales y sin razonamientos humanos, con auto-abnegación y pleno control de las inclinaciones naturales (...).” BENEDICTO XIV. De servorum Dei beatificatione et beatorum canonizatione. In: Opera omnia, III, Prato, 1840, chs. XXXI-XXXVIII. Apud ecwiki — Enciclopedia Católica Online. Disponível em: <http://ec.aciprensa.com/wiki/Virtudes_heroicas>. Acesso em: 15 mar. 2017.

${ }^{76}$ ZURARA, Gomes Eanes de. Crónica da Tomada de Ceuta, op. cit., p. 289.

${ }^{77}$ ÁLVAREZ, João. Chronica do Infante Santo D. Fernando, op. cit., p. 6.

${ }^{78}$ LOPES, FERNÃO. Cronica del rei Dom João I de boa memoria. Parte Segunda. Edição de William J. Entwisle. Lisboa: Imprensa Nacional — Casa da Moeda, 1977, p. 3.

${ }^{79}$ ZURARA, Gomes Eanes de. Crónica da Tomada de Ceuta, op. cit., p. 26.

${ }^{80}$ VENTURA, Margarida Garcez. O elogio do contraditório. Reflexôes sobre a cronística de Zurara. In: RIBEIRO, Maria Eurydice de Barros; FRANÇA, Susani Silveira Lemos. A escrita da história de um lado a outro do Atlântico. São Paulo: Cultura Acadêmica, 2018.

${ }^{81}$ ZURARA, Gomes Eanes de. Crónica da Tomada de Ceuta, op. cit., p. 47.

${ }^{82}$ Para uma definição da virtude da fortaleza, ver: Glosa Castellana al "Regimiento de Príncipes" de Egidio Romano (1344). Ediçáo, estudo preliminar e notas de Juan Beneyto Perez. Madri: Centro de Estudios Políticos y Constitucionales, 2005, p. 73.

${ }^{83}$ SENELLART, Michel. As artes de governar. Tradução de Paulo Neves. São Paulo: Editora 34, 2006, p. 190.

${ }^{84}$ ZURARA, Gomes Eanes de. Crónica do Conde Dom Pedro de Meneses, op. cit., p. 485.

${ }^{85}$ ZURARA, Gomes Eanes de. Crónica de D. Duarte de Meneses, op. cit., p. 72.
} 
No conselho que o infante d. Pedro deu ao seu irmão d. Duarte quando este ascendeu ao trono, recomenda-lhe que se conheça a si próprio, sua "tenção e propósito"; tenha persistência e firme vontade; e, ainda, recomenda-lhe que se esforce "no muito siso e virtude" que Deus the tinha dado. ${ }^{86}$ É esse esforço em trabalhar o que tinha sido recebido por dádiva que é reiterado nos diversos relatos. Ao Infante Santo, d. Fernando, diversas vezes é atribuído o mesmo cuidado. Apresentado como "virgem no corpo e na alma", por suas "honestas obras", à moda de célebres cavaleiros como Galaaz — cujas lendas então circulavam ${ }^{87}$-, d. Fernando preservava-se de dizer ou "ouvir palavras feias" ou "torpes", ou seja, evitava os chamados pecados da língua, que estimulavam os prazeres ilícitos, ${ }^{88}$ os "atos de fornízio". ${ }^{89}$ Esse senhor, como destaca o seu cronista, "se abstinha de todas as viandas e cheiros, que provocar [poderiam] os atos luxuriosos". ${ }^{90}$ Do mesmo modo tratava os "simples" com bondade, e "nunca lhe ouviram nomear o diabo" ou jurar em "nome de Deus", pois evitava pronunciar o nome de Deus em vão, como recomendavam os grandes pregadores cristãos. ${ }^{91} \mathrm{Nem}$ "toda a sanha do mundo" pôde abalar "seu virtuoso costume". ${ }^{22}$

A outros quatrocentistas ligados ao mar e às conquistas, nesses primeiros tempos em que a África moura era mais uma porta para a "Terra dos Negros", ${ }^{93}$ é similarmente atribuído esforço para fazerem jus àquilo que Deus deu. E um instrumento comumente apresentado para estimular a prática e o aperfeiçoamento do que em essência tinha sido dado é o exemplo das "bondades" dos conterrâneos. Na Crônica de D. Afonso V, o cronista Rui de Pina faz constar que, se já as dignidades e façanhas registradas sobre os barôes estrangeiros "movem para aborrecer os vícios" e "guiam para o caminho de suas louvadas virtudes", muito mais despertam o ânimo as "excelentes virtudes e prósperas empresas de nossos próprios naturais" dadas a conhecer por escrito. Associava, assim, à dádiva divina e ao empenho dos homens, o

\footnotetext{
${ }^{86}$ PINA, Rui de. Chronica do senhor rey D. Duarte. In: Crónicas de Rui de Pina, op. cit., p. 498.

${ }^{87}$ MONGELLI, Lenia Márcia. E Fizerom taes Maravilhas... Histórias de Cavaleiros e Cavalarias. Cotia: Ateliê Editorial, 2012, p. 393-394.

${ }^{88}$ Os pecados da língua são considerados filhos dos pecados capitais e as palavras desonestas, Gil de Roma e outros julgavam capazes de estimular os prazeres ilícitos. CASAGRANDE, Carla; VECCHIO, Silvana. Les péchés de la langue. Discipline et éthique de la parole dans la culture médiévale, op. cit., p. 12, 31 e 283.

${ }^{89}$ ÁLVAREZ, João. Chronica do Infante Santo D. Fernando, op. cit., p. 12.

${ }^{90}$ Idem.

${ }^{91}$ Sobre o uso do nome de Deus em vão ou a ofensa a Deus, ver: CASAGRANDE, Carla; VECCHIO, Silvana. Les péchés de la langue. Discipline et éthique de la parole dans la culture médiévale, op. cit., p. 209 et. seq.

${ }^{92}$ ÁLVAREZ, João. Chronica do Infante Santo D. Fernando, op. cit., p. 17.

${ }^{93} \mathrm{Um}$ dos espaços geográficos definidos pelo cronista, sem muita precisão, para distinguir o território para além da Guiné. LINTE, Guillaume. As 'novas humanidades' na Crónica da Guiné de Gomes Eanes de Zurara. Revista Portuguesa de História, v. 46, p. 15-34, 2015, p. 23-24; BARRETO, Luís Filipe. Gomes Eanes Zurara e o nascimento do discurso historiográfico da transição. In: BARRETO, Luís Filipe. Descobrimentos e Renascimento: formas de ser e pensar nos séculos XV-XVI. Lisboa: Comissariado para a XVII Exposição Europeia de Arte, Ciência e Cultura, 1985, p. 63-125.
} 
poder dos escritos de dar a conhecer os modelos a serem seguidos..$^{94}$ Escritos que, na forma de "história", como ele diz, ajudariam, como uma "liberal princesa de todo bem", a vermo-nos acrescidos "em toda qualidade de bondades e virtudes espirituais e corporais". A partir do contato com a história, acrescenta Pina, achar-nos-íamos "logo outros, e sentir[íamos] em nós um outro singular melhoramento". ${ }^{5}$

Por fim, uma outra maneira, não incomum, ${ }^{96}$ de conjugar a intervenção divina e o aperfeiçoamento das virtudes por empenho humano é o sofrimento, ou padecimento. Na história do infante d. Fernando, seu citado confessor, frei Joáo Álvares, destaca que o "dom divinal", mais que "outro humano trabalho" foi o que mais pesou para que ele viesse a ser "mui ensinado na santa Escritura e em todos os morais costumes". E fornece um dado sobre a forma da intervenção divina: "em toda sua vida teve continuamente dor de coração, qual coisa Deus pôs nele e conservou muitas virtudes entanto"; ${ }^{97}$ de modo que "mais quis semelhar a sua conversação angélica que humana", além de ter sido dotado de várias outras virtudes notáveis. ${ }^{98}$

Outra das palavras que merece atenção por sua constância nas narrativas é a obediência. Peça-chave da relação cristã com o divino ${ }^{99}$ e das formas de afirmação da realeza, ${ }^{100}$ ela aparece emaranhada a esses referidos dois eixos da moralidade quatrocentista portuguesa - eixos que tanto remetem aos santos e a outros cristáos exemplares quanto permitem perceber as novas nuances incorporadas no período em questáo. Entendida não apenas como acatamento de uma ordem, ela traduzia uma reverência a uma vontade superior, a de Deus, e um reconhecimento de que o único poder legítimo vinha dele. ${ }^{101}$ Por isso, era uma reverência do espírito, mas que se manifestava nos gestos e nas palavras, pelo corpo e pela boca. ${ }^{102}$ Fundada na ideia de cumprimento dos mandamentos e de fé incondicional a Deus, ela se

\footnotetext{
${ }^{94}$ PINA, Rui de. Chronica do senhor rey D. Affonso V. In: Crónicas de Rui de Pina, op. cit., p. 584.

${ }^{95}$ Ibidem, p. 487.

${ }^{96}$ A rainha d. Isabel, por exemplo. Cf. Vida e Milagres de Dona Isabel, Rainha de Portugal. Texto do século XIV, restituído à sua presumível forma primitiva e acompanhado de notas explicativas por J. J. Nunes. Coimbra: Imprensa da Universidade, 1921, (Academia das Ciências de Lisboa. Separata do Boletim de Classe de Letras.) v. III.
}

${ }^{97}$ ÁLVAREZ, João. Chronica do Infante Santo D. Fernando, op. cit., p. 8. Vale destacar que sobre "entanto, adv. (do lat. intantu-m). Entretanto. Formas: ê táto (VC, 2); em tamto (TC, 1; VC, 2); em tanto (VC, 17); em tấto (VC, 10; HV, 1;EE, 3); emtanto (VC, 1); en tanto (EE, 1); entanto (VC, 2); entáto (VC, 1). MACHADO, José Barbosa (Ed.). Dicionário dos primeiros livros impressos em língua portuguesa, op. cit., p. 294, v. 2.

${ }_{98}$ ÁLVAREZ, João. Chronica do Infante Santo D. Fernando, op. cit., p. 8.

99 Já que tudo existe por Deus e para Deus, havendo uma dependência intransponível ao seu governo. GILSON, Étienne. O espirito da filosofia medieval, op. cit., p. 177 e 210.

${ }^{100}$ SORIA, José Manuel de. La Realeza. In: SORIA, José Manuel de (Dir). Origenes de la monarquía hispânica. Propaganda y legitimación (c. 1400-c. 1520). Madri: Librería-Editorial Dykinson, 1999, p. 39.

${ }^{101}$ BOULNOIS, Olivier. Os escolásticos, Boaventura (cerca de 1220-1274), Tomás de Aquino (1225-1274), Duns Scotus (1265-1308): Beatitude, Lei Natural e Pobreza. In: CAILLÉ, Alain; LAZZERI, Christian; SENELLART, Michel. História argumentada da filosofia moral e politica: a felicidade e o útil, op. cit., p. 170-171. ${ }^{102}$ CASAGRANDE, Carla; VECCHIO, Silvana. Les péchés de la langue. Discipline et éthique de la parole dans la culture médiévale, op. cit., p. 182. 
manifestava nos virtuosos na forma de lealdade ao rei e de aceitação inconteste da hierarquia social. ${ }^{103} \mathrm{O}$ infante d. Fernando, por exemplo, "ainda que (...) em todo tempo fosse mui solícito e disposto para amar e servir o rei seu pai e o rei Duarte seu irmão, nunca por isso falecia das coisas que pertenciam ao amor e obediência e serviço de Deus!" Ou seja, era julgado especialmente virtuoso por obedecer em uma ordem que partia de Deus, passava pelo rei e dispersava em escala; uma ordem em que o rei era situado como exemplo na prática das virtudes, a começar pela justiça. ${ }^{104}$

Ao pai, a obediência é também uma das louvadas. O condestável de Portugal, Nuno Álvarez Pereira, "mesurado por natureza" e reconhecido por virtudes que lhe garantiram sair sempre vitorioso nos diversos enfrentamentos que a vida lhe reservou, é um daqueles que se mostra "mais obediente" a seu pai, tendo-se submetido a casar mesmo sem ter vontade. ${ }^{105}$ À semelhança dessa obediência, o conde d. Duarte de Menezes declara ao seu pai, d. Pedro de Menezes, seu desejo, em sua ausência em Ceuta, de lhe "ser sempre muito obediente", não apenas no que fosse proveitoso, "mas em todas as coisas quaisquer que sejam". ${ }^{106}$ Mais emblemática que tal reverência é, entretanto, aquela a d. João I por seus filhos, afinal este conjugava as condiçóes de rei e pai. D. Duarte, em um célebre capítulo do Leal conselheiro, louva a obediência como melhor que o sacrifício, pois aquela seria filha da lealdade e da humildade. ${ }^{107} \mathrm{O}$ rei autor louva todas as faces da obediência, desde o cumprimento de ordens até a abdicação da própria vontade em nome de satisfazer ao pai, à semelhança do que era devido a Deus. ${ }^{108}$ Obediência que, em um conselho que seu irmão d. Pedro lhe dá quando ascende ao trono, segundo conta Rui de Pina, devia continuar, até mesmo depois da sua morte, no encaminhamento do que o pai tinha iniciado ou projetado. D. Duarte, recomendava o irmão, devia "satisfazer[-se]" por seu pai e, assim como em sua vida tinha sido "o melhor e mais obediente filho", devia despois da morte mostrar o "verdadeiro amor". 109

O Eloquente concebe a obediência como uma das manifestaçôes do que é reto, justo, direito, ${ }^{110}$ descrevendo como a sujeição consentida ao pai foi reproduzida posteriormente para o bom acordo e a lealdade entre os irmáos. ${ }^{111}$ Sugere uma plenitude do seu uso que,

\footnotetext{
${ }^{103}$ GAMA, José. A filosofia da cultura portuguesa no Leal Conselheiro de D. Duarte, p. 74-75.

${ }^{104}$ CALAFATE, Pedro. História do Pensamento Filosófico Português, p. 387.

${ }^{105}$ Chronica do Condestabre de Portugal, p. 8-9.

${ }^{106}$ ZURARA, Gomes Eanes de. Crónica de D. Duarte de Meneses, p. 66.

${ }^{107}$ DOM DUARTE. Leal Conselheiro, p. 430-431.

${ }^{108}$ GAMA, José. A filosofia da cultura portuguesa no Leal Conselheiro de D. Duarte, op. cit., p. 104.

${ }^{109}$ PINA, Rui de. Chronica do senhor rey D. Duarte. In: Crónicas de Rui de Pina, op. cit., p. 497.

${ }^{110}$ GAMA, José. A filosofia da cultura portuguesa no Leal Conselheiro de D. Duarte, op. cit., p. 137. Uma associação que faz ecoar a identificação agostiniana entre justiça e obediência à lei divina. SENELLART, Michel. O Policraticus de João de Salisbury (1115/20-1180): Uma ética real da salvação pública. In: CAILLÉ, Alain; LAZZERI, Christian; SENELLART, Michel. História argumentada da filosofia moral e politica: a felicidade e o útil, op. cit., p. 158.

${ }^{111}$ DOM DUARTE. Leal Conselheiro, op. cit., p. 432 e PINA, Rui de. Chronica do senhor rey D. Duarte. In: Crónicas de Rui de Pina, op. cit., p. 497.
} 
entretanto, é corroborada apenas em parte por Rui de Pina. O cronista a confirma no que diz respeito ao infante d. Pedro. Conta que, tendo se atrasado para a cerimônia de "levantamento e obediência geral" do seu irmão d. Duarte, em que seriam ratificados seus direitos como novo rei, o infante, "não esquecido da obediência, amor que a seu irmão devia e tinha, lhe enviou uma carta desculpando-se com muito acatamento por não ir mais asinha". ${ }^{112} \mathrm{D}$. Henrique, igualmente, porque "a principal virtude que tinha e que mais estimava era obediência ao rei", não deixou que a sua lealdade ao irmão fraquejasse. ${ }^{113} \mathrm{O}$ infante $\mathrm{d}$. Fernando, entretanto, diferentemente dos irmáos mais velhos, embora não importunasse diretamente o rei com seus planos de ir a Tânger, "náo deixava de se agravar disso em sua ausência", e a pessoas que faziam chegar suas reclamaçôes ao rei. ${ }^{114}$

A obediência ao soberano, como se vê, é a que mais recorre nos relatos, avançando daquela que garantiu a unidade do território àquela que garantiu sua expansão por outros lugares. Conta Zurara que d. João I, por seus feitos, alcançou a obediência das várias partes do reino que eram insubmissas quando ascendeu ao trono. ${ }^{115}$ Depois, ele e seus sucessores, graças à lealdade dos seus capitães, conseguiram que seus nomes fossem elevados à categoria de defensores da fé católica pelos contemporâneos de outras partes. ${ }^{116}$ O biógrafo do Infante Santo, frei Joáo Álvarez, do mesmo modo, conta que os senhores capitães da armada para Tânger, os infantes d. Henrique e d. Fernando e o conde de Arraiolos, d. Fernando, diante da vontade do rei, "com toda reverência e obediência se dispuseram logo a cumprir seu mandado", apesar de não desconhecerem o "quanto esta conquista era perigosa, assim por azo da pouca gente que levavam", da "multidão de adversários, bem como pelo alongamento da terra". 17

Para os reis que queriam manter firme a sua legitimidade, a obediência a ser prezada era confundida com adesão, ${ }^{118}$ isto é, aquela de boa vontade. Nas palavras fixadas na Crônica da Tomada de Ceuta: "obediência constrangida nunca se pode possuir sem grande suspeita."119 Rui de Pina chega até mesmo a contemplar uma dimensão compensatória da obediência para realizaçáo de obra táo estimada como era a de escrever a história. Ao atualizar a tópica da humildade de que se valem os cronistas do seu tempo, recorre à ideia de que era arriscado que fosse escrita tal obra por cronista de pouca doutrina. Mas justifica que ele, por desejo "de sempre bem e lealmente servir Vossa Real Senhoria, e inteiramente lhe obedecer", aspirava

\footnotetext{
${ }^{112}$ PINA, Rui de. Chronica do senhor rey D. Duarte. In: Crónicas de Rui de Pina, op. cit., p. 495.

${ }^{113}$ Ibidem, p. 516.

${ }^{114}$ Idem.

${ }^{115}$ ZURARA, Gomes Eanes de. Crónica da Tomada de Ceuta, op. cit., p. 46.

116 Viajes por España de Jorge de Einghen, del Baron Leon de Rosmithal de Blatna, de Francisco Guicciardini y de Andrés Navajero. Tradução, anotação e introdução de d. Antonio María Fabié. Madri: Librería de los Bibliófilos, 1879, p. 29.

${ }^{117}$ ÁLVAREZ, João. Chronica do Infante Santo D. Fernando, op. cit., p. 21.

118 GONZALEZ, Maria A. Las ciudades. In: SORIA, José Manuel de (Dir.). Origenes de la monarquía hispânica. Propaganda y legitimación (c. 1400-c. 1520), op. cit., p. 106.

119 ZURARA, Gomes Eanes de. Crónica da Tomada de Ceuta, op. cit., p. 102.
} 
que, "pelo merecimento de [sua] obediência", fosse "relevado do erro da ignorância e temerária ousadia" de se aventurar pelo registro histórico de tão elevados feitos. ${ }^{120}$

Como ornamento de todas essas formas, à Igreja era também exaltada a obediência nas narrativas quatrocentistas sobre os primeiros avanços expansionistas. Muitas vezes subentendida sob a forma de devoção, ${ }^{121}$ não são, entretanto, poucas as vezes em que é referida como motivo de louvor. Entre aqueles em quem tal submissão virtuosa é destacada estava o exemplar Infante Santo, exaltado como "muito obediente a cumprir os mandados da Santa Igreja" ${ }^{122}$ Estava, igualmente, o não menos exemplar infante d. Henrique, apresentado como "muito obediente a todos os mandados da santa Igreja", ${ }^{123}$ tendo sido inclusive nomeado para comandar a "armada sobre a vila de Tanger, possuída tiranamente pelos mouros, para a submeter ao jugo da santa fé católica”. ${ }^{124}$ Tão obedientes se mostraram eles que o próprio d. Fernando, "entre os mouros nesses dias, por exalçamento da santa fé católica, fez seu acabamento". ${ }^{125}$ Manifesta na forma de defesa da fé católica para além do território cristão, a obediência desses homens — incluindo os governadores de Ceuta e outros nobres — aos mandados da Igreja ganhava corpo no seu destemor de partir para terras de mouros para trabalhar "por suas armas por honra do reino e exalçamento da santa fé". ${ }^{126}$ Por obediência e adesão à fé católica, como explica Zurara no tom elogioso que caracteriza a história de então, d. Henrique passou a vida "cercado de gente de diversas naçôes", ${ }^{127}$ e sem perder de vista seu dever de príncipe "tão católico": espionou os "inimigos" de outra fé; buscou supostos príncipes cristãos em outras terras para apoiá-lo; e tentou trazer à santa fé "todas as almas que se quisessem salvar" ${ }^{128}$ Obediência a Deus, ao rei, ao pai, ao senhor, ao irmão mais velho, ao capitão e à igreja, foi não apenas recomendada, mas sobretudo entendida como virtude de que outras seriam decorrentes.

Graça, virtude e obediência, três palavras que, para concluir, por suas articulaçóes entre si, bem como por manterem elos com o passado e estabelecerem parâmetros para o futuro, foram aqui lidas não propriamente como um esqueleto estável da moralidade cristá, em que as verdades aparentemente universais atravessam os tempos, gerando a ilusão de serem trans-históricas ${ }^{129}$ e de aniquilarem as especificidades de um determinado quadro histórico. ${ }^{130}$ Tais

\footnotetext{
${ }^{120}$ PINA, Rui de. Chronica do senhor rey D. Affonso V. In: Crónicas de Rui de Pina, op. cit., p. 584-585.

${ }^{121}$ SCHMITT, Jean-Claude. O corpo, os ritos, os sonhos, o tempo: ensaios de antropologia medieval. Tradução de Maria Ferreira. Petrópolis: Vozes, 2014, p. 108.

122 ÁLVAREZ, João. Chronica do Infante Santo D. Fernando, op. cit., p. 8.

${ }^{123}$ ZURARA, Gomes Eanes de. Crónica de Guiné, op. cit., p. 24.

${ }^{124}$ ÁLVAREZ, João. Chronica do Infante Santo D. Fernando, op. cit., p. 21-22.

${ }^{125}$ Ibidem, p. 3.

${ }^{126}$ ZURARA, Gomes Eanes de. Crónica de Guiné, op. cit., p. 32.

${ }^{127}$ Ibidem, p. 37.

${ }^{128}$ Ibidem, p. 45.

${ }^{129}$ VEYNE, Paul. Foucault. Seu pensamento, sua pessoa. Tradução de Marcelo Jacques de Morais. Rio de Janeiro: Civilização Brasileira, 2011, p. 23.

${ }^{130} \mathrm{O}$ que Michel Foucault chama de discurso, e que Paul Veyne explica ser "a descrição mais precisa, mais
} 
palavras dos relatos e crônicas — ou da memória escrita do reino — , ao contrário, foram aqui analisadas como peças de um jogo, no Portugal quatrocentista, em que a intervenção divina, o desempenho dos homens e a sua submissão ao imaterial permitem perceber que a ética fundada na vida virtuosa ganhou matizes de uma ética cavaleiresca alimentada pelo sonho de ampliação espacial do reino e da fé católica. Nesse contexto específico, o poder laico, especialmente dos reinos ibéricos, arvora-se defensor por excelência, acima até do papado, da fé católica em territórios de mouros e gentios. Conjugando interesses comerciais e expansionistas àqueles de fundo espiritual vindos de longa data, ${ }^{131}$ reis e senhores desses reinos do sul ganham, nas narrativas destinadas a contar suas histórias, o papel de emissários da vontade de Deus na nova evangelização por lugares tomados por inimigos de Cristo, apresentando-se como dotados de disposição para cumprir o desígnio divino de ampliar o reino cristão. Mostram-se, por isso, tementes àquele que justifica quaisquer ações e deve ser finalidade destas. Nesse tempo em que a Península Ibérica tem seus conflitos internos apaziguados, graças aos sucessos de d. João I, os santos perdem seu protagonismo como homens exemplares e ganham prestígio os reis conquistadores e os virtuosos navegadores em terras estrangeiras.

\section{Referências bibliográficas}

ARMAS, Gregório. La moral de San Agustin. Madri: Asilo de Huérfanos del Sagrado Corazón de Jesus, 1955.

ÁLVAREZ, João. Chronica do Infante Santo D. Fernando. Edição crítica por Mendes dos Remédios. Coimbra: F. França Amado, 1911.

BAÑOS VALLEJO, Fernando. Las vidas de santos en la literatura medieval española. Madri: Laberinto, 2003.

BARRETO, Luís Filipe. Gomes Eanes Zurara e o nascimento do discurso historiográfico da transição. In: BARRETO, Luís Filipe. Descobrimentos e Renascimento: formas de ser e pensar nos séculos XV-XVI. Lisboa: Comissariado para a XVII Exposição Europeia de Arte, Ciência e Cultura, 1985, p. 63-125.

BENEDICTO XIV. De servorum Dei beatificatione et beatorum canonizatione. In: Opera omnia, III, Prato, 1840, chs. XXXI-XXXVIII. Apud. ecwiki - Enciclopedia Católica Online. Disponível em: <http://ec.aciprensa.com/wiki/Virtudes_heroicas>. Acesso em: 15 mar. 2017.

concisa de uma formação histórica em sua nudez, é a atualização de sua última diferença individual. Ir assim até a differentia ultima de uma singularidade datada exige um esforço intelectual de apercepção: é preciso despojar o acontecimento dos drapeados demasiado amplos que o banalizam e racionalizam". VEYNE, Paul. Foucault. Seu pensamento, sua pessoa, p. 16-17.

${ }^{131}$ As motivaçôes das primeiras viagens deram ensejo a debates e estudos, entre os quais vale destacar a síntese de GODINHO, Vitorino Magalhães. A expansão quatrocentista portuguesa: problemas das origens e da linha de evolução. Lisboa: Empresa Contemporânea de Ediçóes, 1944, p. 38. 
BOISSELIER, Stéphane; DARBORD, Bernard; MENJOT, Denis. Langues Médiévales Ibériques. Domaines espagnol et portugais. MARTIN, George; MOLÉNAT, Jean-Pierre; TEYSSIER, Paul (Col.). Turnhout: Brepols Publishers, 2012. (Collection L'Atelier du Médiéviste 12.)

BOULNOIS, Olivier. Os escolásticos, Boaventura (c. 1220-c. 1274), Tomás de Aquino (1225-1274), Duns Scotus (1265-1308): Beatitude, Lei Natural e Pobreza. In: CAILLÉ, Alain; LAZZERI, Christian; SENELLART, Michel. História argumentada da filosofia moral e política: a felicidade e o útil. São Leopoldo: Unisinos, 2004, p. 169-184.

CAILLÉ, Alain; LAZZERI, Christian; SENELLART, Michel. História argumentada da filosofia moral e politica: a felicidade e o útil. Sáo Leopoldo: Unisinos, 2004.

CALAFATE, Pedro. História do pensamento filosófico português. Lisboa: Caminho, 1999.

CARVALHO, Mário Santiago de. Uma modernidade perdida. Da melancolia à alegria racional na antropologia do homem superior, segundo D. Duarte. Revista Filosófica de Coimbra, n. 43, p. 187-206, 2013.

CASAGRANDE, Carla; VECCHIO, Silvana. Les péchés de la langue. Discipline et éthique de la parole dans la culture médiévale. Paris: Cerf, 1991.

Chronica do Condestabre de Portugal. Com revisão, prefácio e notas por Mendes dos Remédios. Coimbra: França Amado, 1911.

COELHO, Maria Helena da Cruz. O Estado e as sociedades urbanas. In: COELHO, Maria Helena da Cruz; CARVALHO HOMEM, Armando Luís de (Org.). A génese do Estado Moderno no Portugal tardo-medievo (séculos XIII-XV). Ciclo temático de conferências organizado pela Universidade Autónoma de Lisboa no ano letivo de 1996/1997. Lisboa: Universidade Autónoma de Lisboa, 1999, p. 269-292.

DE ANDRADE, António Alberto Banha. Mundos novos do mundo: panorama da difusão, pela Europa, de notícias dos descobrimentos geográficos portugueses. Lisboa: Junta de Investigaçōes do Ultramar, 1972.

DELHAYE, Ph.; LECLERCQ, J.; HÄRING, B.; VOGEL, C.; NODET, Ch. H. La pastorale du péché. Tournai: Desclée \& Cie, 1961.

DOM DUARTE. Leal conselheiro. In: Obras dos principes de Avis. Edição de Manuel Lopes de Almeida. Porto: Lello \& Irmão — Editores, 1981.

. Livro da ensinança de bem cavalgar toda. Edição crítica por Joseph M. Piel. Lisboa: Imprensa Nacional — Casa da Moeda, 1986.

DOM PEDRO. Livro da virtuosa benfeitoria. In: Obras dos príncipes de Avis. Ediçâo de Manuel Lopes de Almeida. Porto: Lello \& Irmão — Editores, 1981.

DUPRONT, Alphonse. Du sacré: croisades et pèlerinages - images et langages. Paris: Gallimard, 1987. 
FOURNIÉ, Michelle; LE BLÉVEC, Daniel; HENRIET, Patrick et al. La parole sacré. Formes, fonctions, sens (XI $\mathrm{XV}^{\mathrm{e}}$ siècle). Cahiers de Fanjeaux - Publication annuelle d'histoire religieuse du Midi de la France au Moyen Âge 47. Toulouse: Privat, 2013, p. 15. GADAMER, Hans-Georg. Verdade e método. Traços fundamentais de uma hermenêutica filosófica. Tradução de Flávio Paulo Meurer; revisão de Ênio Paulo Giachini. Petrópolis: Vozes, 1999, 2v.

GAMA, José. A filosofia da cultura portuguesa no Leal Conselheiro de D. Duarte. Lisboa: Fundação Calouste Gulbenkian, 1995.

GILSON, Étienne. A filosofia na Idade Média. Tradução de Eduardo Brandão. São Paulo: Martins Fontes, 2001.

. O espirito da filosofia medieval. Traducão de Eduardo Brandão. São Paulo: Martins Fontes, 2006.

Glosa Castellana al "Regimiento de Príncipes" de Egidio Romano. Edição, estudo preliminar e notas de Juan Beneyto Perez. Madri: Centro de Estudios Políticos y Constitucionales, 2005. GODINHO, Vitorino Magalhães. A expansão quatrocentista portuguesa: problemas das origens e da linha de evolução. Lisboa: Empresa Contemporânea de Ediçôes, 1944.

GUENÉE, Bernard. Entre l'Église et l'État. Paris: Gallimard, 1987.

LAUAND, Jean. Razão, natureza e graça: Tomás de Aquino em sentenças. São Paulo: Edix, 1995. Disponível em: <http://www.hottopos.com/mp3/sentom.htm\#agra>. Acesso em: 30 abr. 2017. LINTE, Guillaume. As 'novas humanidades' na Crónica da Guiné de Gomes Eanes de Zurara. Revista Portuguesa de História, v. 46, p. 15-34, 2015.

LOPES, Fernão. Cronica del rei Dom João I de boa memoria. Parte Segunda. Edição de William J. Entwisle. Lisboa: Imprensa Nacional — Casa da Moeda, 1977.

MACHADO, José Barbosa. Dicionário dos primeiros livros impressos em língua portuguesa. Braga: Ediçóes Vercial, 2015, 4v.

MARQUES, Oliveira A. H. Nova história da expansão portuguesa. Vol. II: A expansão quatrocentista. Lisboa: Estampa, 1998.

MARROU, Henri-Irenée. Saint Augustin et l'augustinisme. Paris: Seuil, 2003.

MONGELLI, Lenia Márcia. E Fizerom taes Maravilhas... Histórias de Cavaleiros e Cavalarias. Cotia: Ateliê Editorial, 2012.

NIETO SORIA, José Manuel. Imágenes religiosas del rey y del poder real en la Castilla del siglo XIII. En la España medieval, v. 9, p. 709-729, 1986.

PEREIRA, Duarte Pacheco. Esmeraldo de Situ Orbis. Introdução e anotaçôes históricas de Damiāo Peres. Lisboa: Academia Portuguesa de História, 1988.

PINA, Rui de. Chronica do senhor rey D. Affonso V. In: Crónicas de Rui de Pina. D. Sancho I, D. Afonso II, D. Sancho II, D. Afonso III, D. Dinis, D. Afonso IV, D. Duarte, D. Afonso V, D. João II. Introd. e rev. de M. Lopes de Almeida. Porto: Lello \& Irmão, 1977. 
. Chronica do senhor rey D. Duarte. In: Crónicas de Rui de Pina. D. Sancho I, D. Afonso II, D. Sancho II, D. Afonso III, D. Dinis, D. Afonso IV, D. Duarte, D. Afonso V, D. João II. Introdução e revisão de M. Lopes de Almeida. Porto: Lello \& Irmão — Editores, 1977.

RINCÓN, David Nogales. Los espejos de príncipes en Castilla (siglos XIII-XV): un modelo literario de la realeza bajomedieval. Medievalismo: Boletín de la Sociedad Española de Estudios Medievales, n. 16, p. 9-40, 2006.

OLIVEIRA, Fernão de. A Gramática da Linguagem Portuguesa. Introdução, leitura atualizada e notas por Maria Leonor Carvalhão Buescu. Lisboa: Imprensa Nacional — Casa da Moeda, 1975.

RUCQUOI, Adeline. Mancilla y limpieza: la obsesión por el pecado en Castilla a fines del siglo XV. In: Rex, sapientia, nobilitas. Estúdios sobre la Península Ibérica Medieval. Granada: Universidade de Granada, 2006.

SANCHEZ, Clemente. Sacramental. Edição semidiplomática, introdução, lematização e notas de José Barbosa Machado. Braga: Edições Vercial, 2010.

SCHMITT, Jean-Claude. O corpo, os ritos, os sonhos, o tempo: ensaios de antropologia medieval. Tradução de Maria Ferreira. Petrópolis Vozes, 2014.

SENELLART, Michel. As artes de governar. Tradução de Paulo Neves. São Paulo: Editora 34, 2006.

O Policraticus de João de Salisbury (1115/20-1180): uma ética real da salvação pública. In: CAILLÉ, Alain; LAZZERI, Christian; SENELLART, Michel. História argumentada da filosofia moral e politica: a felicidade e o útil. São Leopoldo: Unisinos, 2004, p. $155-160$.

SORIA, José Manuel de (Dir.). Origenes de la monarquía hispânica. Propaganda y legitimación (c. 1400-c. 1520). Madri: Librería-Editorial Dykinson, 1999.

VAUCHEZ, André. Présentation. In: Faire Croire. Modalités de la diffusion et de la réception des messages religieux du XII ${ }^{e}$ au XVe siècle. Org. por l'École Française de Rome, em colaboração com l'Institut d'Histoire Médiévale de l'Université de Padoue (Roma, 22-23 jun. 1979). Paris: École Française de Rome — Palais Farnése, 1981.

VAZ, Henrique C. de Lima. Escritos de filosofia IV. Introdução à ética filosófica. São Paulo: Ediçôes Loyola, 2009.

VENTURA, Margarida Garcez. O elogio do contraditório. Reflexóes sobre a cronística de Zurara. In: RIBEIRO, Maria Eurydice de Barros; FRANÇA, Susani Silveira Lemos. A escrita da história de um lado a outro do Atlântico. São Paulo: Cultura Acadêmica, 2018.

VEYNE, Paul. Foucault. Seu pensamento, sua pessoa. Tradução de Marcelo Jacques de Morais. Rio de Janeiro: Civilização Brasileira, 2011. 
Viajes por España de Jorge de Einghen, del Baron Leon de Rosmithal de Blatna, de Francisco Guicciardini y de Andrés Navajero. Tradução, anotação e introdução de d. Antonio María Fabié. Madri: Librería de los Bibliófilos, 1879.

Vida e Milagres de Dona Isabel, Rainha de Portugal. Texto do século XIV, restituído à sua presumível forma primitiva e acompanhado de notas explicativas por J. J. Nunes. Coimbra: Imprensa da Universidade, 1921, v. III. (Academia das Ciências de Lisboa. Separata do Boletim de Classe de Letras.)

ZURARA, Gomes Eanes de. Crónica da Tomada de Ceuta. Edição de Francisco Maria Esteves Pereira. Coimbra: Imprensa da Universidade, 1915.

. Crónica de D. Duarte de Meneses. Edição diplomática de Larry King. Lisboa: Universidade Nova de Lisboa, 1978.

- Crónica de Guiné. Introdução, novas anotações e glossário de José de Bragança. Lisboa: Livraria Civilização, 1973.

- Crónica do Conde Dom Pedro de Meneses. Nota de apresentação de José Adriano de Freitas Carvalho. Fac-símile da edição do Abade Correia da Serra, de 1792, Academia das Ciências de Lisboa. Porto: Programa Nacional de Ediçôes Comemorativas dos Descobrimentos Portugueses, 1988. 